\title{
Isto não é um índio: pistas éticas para decolonializar uma pesquisa
}

\author{
This is not an indian: ethical clues to decolonialize a research
}

Gustavo Alves Eduardo; Fernando Hiromi Yonezawa

Universidade Federal do Espírito Santo

\section{RESUMO:}

Neste ensaio, propomos tensionar o conceito da história e a questão sobre quem não é indígena, a partir de diversos autores, como Benjamin e Castro, para que daí pontilhemos pistas nubilosas de constituição de uma posição ética decolonial no ato de pesquisar. Investigar-se-á, nas teses sobre o conceito da história, as passagens que forçam o pensamento ao exercício crítico de vetorizar o lugar daqueles tidos como não-indígenas. É nos assombros do cotidiano contemporâneo que enxergamos as atualizações das práticas e discursos colonialistas, nas quais se sustenta uma esclerosada hegemonia, que resulta na perpetuação da relação unívoca com a história universal. Buscar-se-á compreender como nós não-indígenas podemos ocupar um lugar de implicação, através do agenciamento de um texto em linhas, cada uma guardando uma intensidade e experimentando reflexões que apontem para uma ética de implicação decolonial, sem que haja uma ordenação ou continuação das linhas umas em relação às outras.

Palavras-chaves: história; não-indígenas; decolonializar.

\begin{abstract}
:
In this essay, we propose to tension the concept of history and the question about who is not indigenous, from different authors, such as Benjamin and Castro; so that we can point out nubile clues for the constitution of a decolonial ethical position in the researching act. In the theses on the concept of history, it will be investiganting the passages that force thought into the critical exercise of vectorizing those considered to be non-indigenous' place. It is in the haunts of contemporary daily life that we can see the updates of colonialist practices and discourses, which sustain a sclerotic hegemony, that results in the perpetuation of the univocal relationship with universal history. We will try to understand how non-indigenous people can occupy an implication place, agencing a text through lines, each one keeping an intensity and experiencing reflections that point to an decolonial ethics implication, without an order or continuation of these lines related to each other.
\end{abstract}

Key-words: history; non-indigenous; decolonialize.

DOI: 10.12957/mnemosine.2021.61843

\section{Introdução: linha direcional}

Nosso ponto de partida é a idéia de que a obtusa fé no progresso desses políticos, sua confiança no "apoio as massas" e, finalmente, sua subordinação servil a um aparelho incontrolável são três aspectos da mesma realidade. Estas reflexões tentam mostrar 
como é alto o preço que nossos hábitos mentais têm que pagar quando nos associamos a uma concepção da história que recusa toda cumplicidade com aquela à qual continuam aderindo esses políticos (BENJAMIN, 1987: 227).

Partiremos de uma constatação ainda um pouco concisa e frágil de que não são os indígenas, os caboclos, a imprensa ou as ONG's que estão ateando fogo na Amazônia, no Pantanal, ou em todo Brasil. Vale dizer que se fossem estes os responsáveis pelas queimadas, ainda que sob a jurisdição de suas terras, o mundo, talvez, não existiria ou se sustentaria até hoje, pois os motivos históricos, raciais, de gênero, de classe, geográficos e sexuais, que nos antecederam poderiam autorizá-los para realização de tais atos. No entanto, mesmo com muitos motivos para cometerem queimadas deliberadas, não o fizeram, assegurando assim um sopro de vida possível e um acordo secreto com aqueles que vieram antes de nós. Assim, nossa relação com a história, a natureza, o humano, o tempo e o coletivo configuram ou registram em nós um certo modo de vida que se faz no envolvimento entre os seres humanos e inumanos. Nesse sentido, como proposta de articulação teórica e tendo presenciado discursos e práticas que caminham dentro da racionalidade do antropoceno - predatória e retrógrada - presentificada no cotidiano brasileiro, articulamos algumas reflexões teóricas acerca da história e do lugar do nãoindígena implicado. Diante disso, foram as inúmeras informações e notícias veiculadas pelas mídias sociais, que nos provocaram como analisadores, a pensar e articular tais problematizações - acerca disso é que gostaríamos de falar ao longo do texto.

Caso possamos constatar de maneira frágil e pouco concisa de que não são os indígenas os responsáveis pelas queimadas, haveria também por parte das nossas discussões um trabalho de pensar a história diante do tempo que vivemos - exercício esse coextensivo ao longo da vida e emergente diante das práticas e discursos enunciados. Tal emergência nos serve como um momento oportuno no qual podemos enxergar a história por outros ângulos - antes não ditos -, assim como lançar outros olhares, já que "pensar é, primeiramente, ver e falar, mas com a condição de que o olho não permaneça nas coisas e se eleve até as "visibilidades" [...]. É o pensamento como estratégia." (DELEUZE, 2013: 123-124). Olhar a história com outros olhares seria então a possibilidade de enxergá-la não a partir de uma linearidade ou racionalidade hegemônica, mas, também, um movimento de composição de outras perspectivas fora da ordem das "grandes narrativas". Desse modo, pensar e exercitar a construção ou convergência de outros olhares a respeito da história, é estar implicado com uma certa emergência daquilo que assombra os nossos cotidianos e nos força a pensar nossa relação com o mundo que vivemos. Acreditamos 
que, com esse exercício, estaríamos tracejando pistas éticas para um posicionamento de tentativa de saída de uma postura colonial em relação às narrativas, à história, aos acontecimentos, ao tempo, principalmente em relação ao nosso próprio tempo. O nosso autor, Deleuze (2013) já nos dizia, afinal, que precisamos olhar para a história, tal como Foucault o fez: para nos darmos conta daquilo que já não somos mais. E, com certa petulância de completar o filósofo, diríamos que precisamos deslocar a história para nos darmos conta daquilo que já não desejamos mais, para nos lançarmos para fora de uma história que nos impregnou de uma presumida universalidade.

Assim, implicados com a emergência de contrariar, tensionar e afirmar outros olhares acerca daquilo que nos acontece, podemos pensar a história a partir de uma primeira interrogação: como pensar o lugar dos não-indígenas? Quer dizer, como pensar nosso lugar e a implicação com um certo não-lugar? Podemos dizer que tais questões não têm como interesse reafirmar um lugar já instituído na hegemonia dos discursos, pois, neste caso, não haveria um deslocamento propriamente dito acerca daquilo que gostaríamos de pensar, a história por outros ângulos. Ora, caso fosse essa a postura, poderíamos recair na persistência da "[...] ideia de que são universais e falam por todos, insistem em falar pelos outros, quando, na verdade, estão falando de si ao se julgarem universais" (RIBEIRO, 2019: 31). Mas, como bem diz Deleuze (2006), os universais não são mais do que ficções de uma ideia específica, a generalidade é somente uma especificidade que se imbuiu de ares teocráticos, na medida em que se ajuizou apoiada na figura de um suposto Mesmo idêntico a si. A partir daí, poderíamos dizer do processo que é escrever esse texto, cujo o título: “Isto não é um índio” prenuncia a nossa aposta, tendo como referência uma das obras de René Magritte (1928-1929) em “ceci n'est pas une pipe” (Isto não é um Cachimbo), da coleção “A Traição das Imagens”. Intitular o presente trabalho dessa forma é, justamente, uma colocação um tanto provocativa para deslocar o texto de um lugar representativo, cuja queda faz ressoar um outra implicação possível e real diante da experiência do mundo. Assim, tal enunciado não tem como pretensão anunciar ou constatar o que é ser índio, mas, num só tempo, ainda que paradoxal, constituir discussões em torno do lugar dos não-indígenas frente às atuais emergências numa perspectiva de "confluência" entre os diferentes autores e autoras (SANTOS, 2015: 89). Assim, pensamos a confluência a partir do pensamento plurista dos povos politeístas, no qual nem tudo que se junta permanece o mesmo; são as nossas diferenças que nos fazem pensar que, para acessar esse plano dimensional, será preciso transformamos “[...] as nossas divergências em diversidades, e na diversidade atingirmos a confluência de 
todas as nossas experiências" (SANTOS, 2015: 91).

Para tanto, no processo de elaboração da escrita desse texto, o que se escreve é, justamente, a implicação enquanto uma postura que coexiste aos acontecimentos que "[...] opõe-se radicalmente às pretensões de objetividade fixadas pelos pesquisadores em ciências sociais", assim mesmo o observador de um acontecimento pode já estar implicado com esse campo de observação (LOURAU, 2004: 82). Assim, o olhar, o pensar ou analisar, é parcialmente uma postura da presença que dimensiona um campo de relações. Assim, pensamos e escrevemos entendendo que "[...] o que se opõe ao tempo assim como à eternidade, é nossa atualidade" (DELEUZE, 2013: 123). Portanto, pensamos aqui frente aos acontecimentos mais presentes, como os discursos enganosos, os desmatamentos, as queimadas, os interesses comerciais sobre os manguezais, a pandemia, o racismo e as inverdades enunciadas a respeito dos povos da floresta. Haveria duas possibilidades de experimentar estes acontecimentos: recolher-se ou efetuar-se neles. Isto é, “[...] rejuvenescer e envelhecer a um só tempo, em passar por todos os seus componentes ou singularidades. [...] desviar-se a fim de "devir", isto é, para criar algo novo" (DELEUZE, 2013: 215). Assim, por mais que apresentemos uma articulação teórica, esta vem implicada com a atualidade daquilo que observamos, experimentamos e escutamos em nossos cotidianos, estando inteiramente atravessada pelo intempestivo daquilo que vivenciamos.

Assim, ainda que escrevemos a respeito daquilo que acontece no ano de 2020, também é incerto dizer que tudo isso aconteceu conforme escrevemos, pois aquilo que elaboramos a partir dessas experiências são, propriamente, apenas algumas passagens. Afinal, escrever na contemporaneidade de um acontecimento é, como diria Agamben (2009), ter a espinha lesionada e entortada pelos males do tempo em que se vive e, simultaneamente, ver-se já cavando uma saída para esse espírito do tempo, ver-se desgostoso do próprio momento atual que se comunga com os outros. Mas, também, não se trata de decalcar uma verdade a respeito da história, pois não estamos apenas a denunciar os horrores do presente, e sim exercitarmos um olhar para outras visibilidades e cultivar nelas outras composições vitais. Estamos, talvez, denunciando a própria ideia de verdade como sendo uma espécie de ideia-dispositivo de colonização e monoculturalização do mundo. Não à toa, é a monocultura extensiva a grande prática de savanização de nossas matas mais vivas e entremeadas de uma multiplicidade de povos e espécies: essa monocultura é efeito da verdade, essa peçonha colonial com pretensões monoculturais. Assim, escrevemos não apenas para compartilhar informações, mas, 
também, para deslocar o pensamento, o olhar, a postura e o agir, provocando a inquietação e os paradoxos daquilo que se chamou história universal, e isto é um exercício complexo do pensamento nesse contexto que nos força a criar outros modos de relação consigo e o outro. Tratar-se-à, pois, de um escrever que busca pistas éticas para sair da verdade e, portanto, da colonialidade; e, certamente, essas pistas não serão mais do que pontilhados nubilosos, bastante míopes ainda, contaminados que sempre estamos da visão ciclópica do mundo e do tempo histórico. São pistas éticas que vetorizam um modo de pesquisar e, sobretudo, um modo de sentir, olhar e transformar a história do mundo em milhares de histórias dos milhares de mundos.

Então, partimos da questão: “como pensar o lugar dos não-indígenas?”. Por vezes, no campo da academia, das políticas públicas, o descuido, a ingenuidade, o antro(etno)pocentrismo ou o canibalismo da postura de se colocar sobre o outro pode nos realocar numa lógica colonialista e fantasiosa em responder às seguintes questões: o que é ser indigena? Ou ainda, de quem é a voz que ecoa entre as vozes que já foram silenciadas? O que é sermos não-indígenas e qual é, paradoxalmente, nosso lugar de deslocamento, nosso lugar de desterritorialização ética?

Este lugar de partida, com estas questões, já poderia ser, então, uma indicação desta contemporaneidade que, em nós, insiste em exteriorizar-se de si, para olhar para um tempo em devir que, por isso mesmo, não tem forma, mas nos força e nos instiga a uma outra ética, a um outro valor ou outro peso de nossas passadas sobre o mundo? Este ponto de partida já seria um pontinho borrado de pista para o trabalho de pesquisa, que tenta se colocar nessa ética de saída da história universal colonial?

\section{A linha não-dita da história}

O remo de caiçara mergulhava nas águas escuras da maré. A peça auxiliava a canoa a deslizar sobre as águas do manguezal de Aracruz, litoral norte do Espírito Santo. Quanto mais força, mais velocidade. Dentro da canoa, quanto mais distribuído o peso das pessoas e dos objetos, mais equilíbrio ela ganhava. Na condução da canoa de caiçara o remo do lado esquerdo e do lado direito precisam estar numa sincronia de movimentos. Não estando em sincronia, corre-se o risco da canoa perder a direção, ou, até mesmo, virar. Dos manguezais, até a boca do Rio, o cheiro da aroeira, o odor do mangue invade os poros do corpo e compõem aquela manhã de sábado ensolarado, num clima tropical litorâneo típico dessa cidade capixaba, assim como os outros dias da semana, nos quais o tempo parece não passar. Nas casas e nos quintais à beira das estradas e ao longo do 
manguezal percebe-se que a vida transita em movimentos outros tão diferentes quanto aqueles da cidade sede ou das grandes metrópoles. Dos quintais à beira da maré ou das estradas: o corpo ereto e os olhos a fitar acompanham todo princípio de movimento. E a canoa segue na superfície do Rio numa suavidade inconfundível. O chão batido dos quintais, o barro vermelho das estradas, se assemelha à poeira que fica nas folhas das plantas e permite que as casas fiquem com as portas e as janelas abertas por muito tempo durante o dia. Seriam esses alguns dos pequenos afectos de quem experimentou viver parte da vida no interior capixaba: a história, o corpo e os afetos se conectam como a canoa, o remo, as águas da maré e o manguezal. O corpo é todo constituído daquilo que o coloca na posição de simples corpo junto com outros corpos, co-emergido com esses corpos a partir dos licores afectivos que os impregnam uns aos outros num mesmo acontecimento, afectos que os implicam, tensionam, os tecem mutuamente. Com o chão batido, as folhas, o rio, a canoa, a maré, o corpo constitui, mais do que um indivíduo, uma paisagem com mobilidade e vida próprias, uma hecceidade, tal como a definiriam Deleuze e Guattari (1997), isto é, uma individuação inumana, uma articulação de fragmentos vetorizados uns nos outros que possuem a força de uma inteireza, de uma vida, ainda que muito breve.

A natureza testemunhará, cada mergulho no riacho, cada conversa debaixo da sombra de uma árvore qualquer, cada boiada que passava na estrada e na porta de casa mugindo deixando um certo odor, porque aí, nessa paisagem sem sujeito, o corpo de um homem é apenas uma força impessoal, implicada e desenvolvida por descentrados afectos, que são, em todos os sentidos, não-humanos. "Você tem a individuação de um dia, de uma estação, de um ano, de uma vida (independentemente da duração); de um clima, de um vento de uma neblina, de um enxame, de uma matilha (independentemente da regularidade)" (DELEUZE; GUATTARI, 1997: 49). É a natureza que testemunha tudo isso, são os riachos, manguezais, canoas e estradas de chão terroso que constituem o corpo da história. Tempos após tempos, algumas coisas mudam. As formas entram em princípios de conversão, os cheiros e odores na sua maioria são os mesmos, as cores modulam, mas numa certa medida: casas; telhados novos; asfalto; cercas de arame; dispositivos tecnológicos como antenas parabólicas e de internet são instalados como registros de acesso ao mundo. A alvenaria das casas e as cores têm seus contornos simples modificados. Da canoa que escorre pelas águas, os traçados e as linhas exibem uma outra vida possível, outros ritmos, tempos, histórias. No entre-meio dos verdes da mata, a fumaça no alto anuncia que o fogão a lenha foi aceso e que os preparativos do almoço 
trariam à mesa o indiscutível e delicioso conjunto caseiro envolvendo temperos, aromas e sabores caipiras.

Momentos festivos anuais, regados por uma mesa farta, acompanhados de músicas, bebidas e diálogos intermináveis registravam a duração do tempo de festejar, partilhar o com[um] em meio aos deliciosos preparativos caseiros. Dos diálogos intermináveis ressoavam histórias, afetos, risos e narrativas tresloucadas, gozações, fatos curiosos, lendas, mistérios, alegrias e gracejos. Gente na sala, na cozinha, criança caindo e ralando o joelho no chão, o cheiro do perfume barato, ou, talvez, o aroma do leite de rosas que pela casa e no quintal ajudam a forjar a constituição de mais uma experiência coletiva, colorindo assim a vida nos mais ínfimos gestos de uma história a mais para ser contada. Fugidias linhas e miudezas ornam o dia-a-dia, apenas os desavisados com os olhos e a atenção colonizada não conseguem ver as miudezas modificando a história. $\mathrm{O}$ detalhe do detalhe pode se revelar enquanto um presente diamantino, ou desalento amargo para alguns, - quando não retiram o olhar daquilo que é visível, as diferenças das histórias e dos outros acabam sendo tomadas apenas como oposições desinteressantes. Atenção às miudezas e ao desassossego, como diria o poeta, pois elas podem desejar sussurrar algo para nós. O céu azul e rosa ao final do dia, como as cores da bandeira do Estado, prenuncia o final de mais um dia na cidade da pedra do altar da cruz. Agora, os corpos se recolhem para a chegada da noite, é tempo de descanso. Encontramos, pois, uma primeira e enevoada pista ética para a pesquisa implicada com nossa não-indigenidade: assumir uma implicação decolonial no ato de pesquisar talvez seja preocupar-se muito mais com a constituição de uma sensibilidade ou de uma afinação háptica no fazer pesquisa, do que propriamente com uma estrita edificação de natureza metodológica. Assumir os afectos de um campo de encontros e suas linhas de relação, mais do que adotar procedimentos razoavelmente planejados para registrar-se num modelo de história, eis um início de decolonialidade. Talvez haja nisso uma posição disponível a implicar-se com o fato de sermos não-indígenas.

Narrar e aprender a história é olhar o presente, sem esquecer o passado, pois teria o passado razão: de quem é a voz que ecoa em meio as outras vozes já silenciadas? Quais os efeitos de uma relação não respeitosa com os elementos da vida-natureza como a água, o fogo, a terra, o ar? Que resultantes advém de partirmos do esquecimento histórico de que a universalidade é, no fundo, pura especificidade e de que, no fim de qualquer duração de tempo, será esta natureza-vida a testemunha da história? Qual estilo de vida será capaz de existir sem uma relação generosa com o meio que vivemos? Ainda que a história tome 
para si o passado, é também o atual daquilo que nos acontece, um momento fugidio que nos faz crer que a história se constrói no presente daquilo que vivenciamos no intempestivo das nossas relações, ou ainda, "o único prazo de validade é a memória. E a memória tem os seus, como se diz, usos sociais" (CASTRO, 2006: 156). Assim, a história guarda e compõe, ao mesmo tempo, linhas narrativas as quais escapam de um certo "hiperativo linear", isto é, escapam a uma ânsia colonial de impor em tudo alguma homogeneidade; por isso, compreender os acontecimentos do contemporâneo nos faz olhar para o tempo e enxergar sempre algo de parecido frente as atualizações discursivas do presente, pois:

[...] nada do que uma vez aconteceu pode ser dado como perdido para a história. É verdade que só a humanidade redimida será dada a plenitude do seu passado. E isso quer dizer que só para a humanidade redimida o passado se tornará citável em cada um dos seus momentos (BENJAMIN, 2012: 10).

Eis, então, uma historieta que nos tira um pouco deste hiperativo linear e narra (e rasga) em nós não-indígenas uma história não universal. No século passado, o governo do Estado do Espírito Santo, havia concedido à Companhia Ferro e Aço de Vitória (COFAVI) uma área equivalente a dez mil hectares de terras que pertenciam aos povos originários: Tupiniquins e Guarani Mbya, na região do município de Aracruz (SANTOS, 2015). Assim, o território indígena explorado tornou-se um verdadeiro campo de expropriação da madeira para produção de carvão vegetal, assemelhando-se à lógica da colonização; e "vamos compreender por colonização todos os processos etnocêntricos de invasão, expropriação, etnocídio, subjugação e até de substituição de uma cultura pela outra, independentemente do território físico geográfico em que essa cultura se encontra" (SANTOS, 2015: 47-48). No entanto, ainda que sob esses fatos, passados alguns anos, um grupo de empresários viu na região uma vantagem de instituir a empresa Aracruz Celulose. Inaugurar-se-ia um processo, “[...] um drástico processo de derrubada das matas nativas para o estabelecimento da monocultura do eucalipto em larga escala inicialmente para a produção de carvão de siderúrgicas e posteriormente para a produção de celulose" (SANTOS, 2015: 66). Quiçá possamos dizer: "seriam mesmo os índios que põem fogo e desmatam as florestas?”. O que os não-indígenas enxergamos ao vermos a mata em chamas? Vemos a mata? Vemos as chamas? Vemos os corpos fugindo? Ou antevemos empreendimentos? É esse o olho do não-indígena branco? Olho que só vê antevendo, que nunca vê histórias nas chamas e, estranhamente, antevê um futuro de empreendimentos? Nessa ideia de progresso desenfreado, atraídos pelos incentivos e vantagens fiscais oferecidos pelo governo do Estado do Espírito Santo na época, a 
empresa expandiu e passou a explorar ainda mais o território dos Tupiniquins, Guarani Mbya e dos quilombolas de Sapê do Norte (formado por trinta e duas comunidades quilombolas). No ano de 2009, a Aracruz Celulose e o grupo Votorantim Celulose e Papel, se integraram e tornaram-se “[...] a maior produtora mundial de celulose branqueada de eucalipto, respondendo por $24 \%$ da oferta mundial”. Após essa integração, a empresa passou a se chamar Fibria (SANTOS, 2015: 66-67). No mesmo ano, o governo do Estado do Espírito Santo realizou uma operação, após acusar os quilombolas da comunidade de São Domingos do Norte de roubo de eucalipto da ex-Aracruz Celulose, recém denominada Fibria (SANTOS, 2015). Esta operação policial contava com cerca de 100 policiais das tropas especiais de choque e do grupo de apoio operacional da Polícia Militar (SANTOS, 2015). Todos fortemente armados, munidos de cavalos e cachorros treinados.

Mesmo sem provas, cerca de quarenta pessoas do Quilombo de São Domingos do Norte foram presas, transportadas em ônibus e em camburões de dentro da comunidade, que fica na zona rural do município de Conceição da Barra/ES, para a delegacia do município de São Mateus/ES, distante cerca de $40 \mathrm{~km}$ da comunidade. Ficaram detidas das 9 às 18 horas, sem alimentação e sem possibilidade de contato com familiares, advogados ou com outros órgãos públicos (SANTOS, 2015: 67).

Diante disso, percebe-se que já havia aí uma verdadeira tecnologia de guerra, a qual acaba por impingir uma lógica que autoriza a produção de morte nas dimensões físicas e subjetivas das vidas (MBEMBE, 2016; 2020). No entanto, ainda que sob muitos acontecimentos intempestivos, nota-se que há propriamente, por parte dessas comunidades indígenas e quilombolas, uma afirmação de si, isto é, como diria nosso autor, Castro (2006: 142), “só é índio quem se garante". E essa garantia de pertencer e apropriar-se de si, aparece na história nas suas fugidias linhas, para as quais a história universal renega o olhar: reconhece, porém se nega a narrar. Ora, ainda que sob o perigo de morte, há um trabalho por parte dessas vidas, tidas como os vencidos da história, em enfrentar a tal necropolítica, e "é por meio desse confronto com a morte que ele ou ela é lançado(a) no movimento incessante da história” (MBEMBE, 2020: 12). Talvez, falar em contra-colonização nada mais seja do que a compreender como "[...] todos os processos de resistência e de luta em defesa dos territórios dos povos contra colonizadores, os símbolos, as significações e os modos de vida praticados nesses territórios" (SANTOS, 2015: 48). Assim, sustentar o trabalho de contracolonização é, precisamente, sustentar em momentos de perigo um trabalho pulsante de morte no qual a vida só é produzida em espasmos e confrontos com a morte. Isto implica pensar que a morte, enquanto putrefação 
da vida, é vetor daquilo que movimenta não apenas em direção ao estado de conservação que se poupa da destruição. Contudo, há um exercício do pensamento que pressupõe a morte e vive com ela numa estratégia agonística. Mas, nesse exercício de vida e morte, a resistência agonística consiste em sempre poder recontar as histórias, contar mais uma história, para que a história não seja universal, não seja narrativa de uma racionalidade que só antevê empreendimentos. Poder contar sempre mais uma história e, mais ainda, entremear essa nova narrativa com os afectos que tornam toda história, no fim, uma história da natureza-vida perpassada pelos acontecimentos de todos os seus povos, ventos, chãos e riachos, talvez seja isso uma possível pista ética de decolonização da ação investigativa. "E a minha provocação sobre adiar o fim do mundo é exatamente sempre poder contar mais uma história" (KRENAK, 2019: 27). Como já alertava Adichie (2009), a história única impulsiona estereotipias, preconceitos e, pior ainda, rouba a dignidade de povos inteiros.

No jornal, nos documentários, nos filmes, nas telenovelas e nos livros de história, a aparência que retrata e narra a vida indígena é sempre aquela que representa a figura folclórica de quem porta unicamente um cocar, plumas, zarabatanas, colares e às vezes até se mostra desprovida de conhecimento. A questão aqui não é, propriamente, negar ou reduzir tais produções culturais, mas olhar para elas enquanto parte de um todo cuja multiplicidade pode ser vista através, tanto de organizações micropolíticas, quanto de mobilizações macropolíticas num cenário social, a saber: o discurso na assembleia constituinte de 1988, no qual as palavras e os gestos de Ailton Krenak prenunciavam, sem vergonha nenhuma, a questão do que é ser indígena, o que estes desejam (o mesmo Ailton Krenak, neste ano de 2020, é eleito intelectual do ano) (KRENAK, 2018; GIACOMO, 2020); a radical fotografia de Tuíre, a mulher que ornada na mistura do carvão e jenipapo, pressiona com seu facão empunhado o rosto do então engenheiro, Fábio Feldmann, diretor da Eletronorte, no ano de 1989 (MARTINHO, 2020); ou ainda, os inúmeros protestos dos indígenas em Aracruz, em específico, uma ação pela qual fecharam parte da Estrada de Ferro da Vale, no município, sob argumentação do Cacique Toninho: "a água do Rio Doce está contaminando o lençol freático do poço que abastece a nossa terra indígena. Não temos segurança na água que estamos tomando" (CASTRO, 2020). Saberse-ia então que esses processos que partem dos povos originários nas mais diversas dimensões da vida social, demarcam não apenas a terra pela qual estes desejam pisar, andar, nadar, caçar, cultivar e habitar, mas, também, demarcam um território-existencial. Que índio é esse? Onde (e de onde) ele se constitui como linha de vida? Quais afectos o 
corporificam e falam nele?

Ora, a marcação de um território, é a marcação de um campo de afectos, linhas de constituição de relações e de vidas. Novamente, para decolonizar o fazer pesquisa é preciso, talvez, incorporar uma postura háptica, capaz de tatear afectos, o que implica necessariamente em recontar as histórias a partir dos afectos emergidos numa relação de ladeamento com aqueles que vivem e se constituem nos territórios. É preciso desfazer a posição de verticalidade e exterioridade em relação aos territórios pesquisados. Ademais, essa postura háptica nos impele, como não-indígenas, à inquietude de fender as histórias universais, atualmente sedimentadas pelos dispositivos midiáticos, para que os povos desses territórios possam cerzir a história com linhas de sua própria narrativa. Atentarmonos ao exercício de cerzidura histórica, que traz como material os fios de afectos dos acontecimentos não-ditos pela grande história, eis possivelmente um gesto de decolonialização do fazer pesquisa.

\section{Linha em ato: modos de devir e ser.}

No capítulo "No Brasil todo mundo é índio, exceto quem não é”, em entrevistas com Eduardo Viveiros de Castro, na série: encontros (CASTRO, 2006), no uso das aspas acerca de, ou talvez, no uso das questões: "quem é índio ou o que define o pertencimento?", é um uso que aparenta ser uma ação de prudência na qual, por vezes, no campo da academia, insistimos em responder e dizer: o que é ser indígena?

Diria nosso autor que desta questão poderão nascer monstros inofensivos; no entanto, caso não nos atentemos para o que eles estão dizendo ou sussurrando, tal inofensividade dará lugar para um terrível e faminto monstro cujas terras habitam a história universal, o lattes, os periódicos, os estabelecimentos universitários, as capas de revistas, os congressos, as titulações, os textos e o estrelato de quem está por dentro das questões da contemporaneidade. Ou ainda, nos inúmeros projetos de sociedade que versam o progresso, a modernidade, a emancipação, a sustentabilidade e o desenvolvimento. Não queiramos expurgar tudo isto, mas olhar com um certo cuidado os efeitos daquilo que realizamos, é um exercício por vezes complexo, cauteloso, instigante e provocativo, ainda mais quando os termos e os conceitos tidos como high-tech (alta tecnologia) surgem e tomam conta dos enunciados discursivos, que muitas das vezes são

perigosos "porque não é uma renovação autêntica que está em jogo, e sim uma galvanização" (BENJAMIN, 1987: 115). A questão em torno: o que é ser indigena?, é uma problemática - ao menos que sejamos peritos indígenas -, pois, não sendo peritos 
indígenas, tal problema pode nos colocar no lugar de periciar o outro: investigar, avaliar, qualificar, medir ou calcular a proporcionalidade do que é ser ou não ser indígena. Ou seja, tanto o lugar quanto a pergunta elaborada já tem enunciado duas respostas: é ou não é, responder tal questão incidiria um apagamento, exclusão e morte de alguns sob o ângulo daqueles tidos como os peritos que enxergam com seus olhos disciplinados a aparência e não o "modo de devir e de ser" (CASTRO, 2006: 137). Talvez, tal questão não nos serviria mais, provocando assim um exercício outro de elaboração do pensamento, uma vez que "agora, ao contrário, 'todo mundo quer ser índio"” (CASTRO, 2006: 139). Que índio é esse?

Anterior aos dias de hoje, e antes mesmo da constituinte de 1988, não é raro encontrar por aí os ditos "projetos de emancipação", cujas linhas versam em torno dos interesses dos coronéis ou grupos de empresários como a história de Aracruz já nos conta (CASTRO, 2006: 137). No entanto, percebe-se que frente aos inúmeros projetos de progresso o que eles - os coronéis e grupos - desejam é expurgar os indígenas de seus territórios sob a narrativa de que estes atrapalham os supostos projetos de sociedade civilizada, moderna e desenvolvida. Afinal, quem mesmo desde muito tempo vem colocando fogo nas florestas? No entanto, podemos voltar a uma colocação anterior que dizia: índio é quem se garante. Essa garantia é, justamente, uma postura que se sustenta frente ao trabalho de morte. Ou seja, a construção de ações que perseveram pela existência, ainda que os coronéis, o Estado, os grupos de empresários não contassem que os próprios indígenas junto de outras pessoas ao longo do tempo tomassem conhecimento do que desejam pensar e afirmar enquanto projeto de emancipação para suas vidas. Em verdade, a narrativa por parte do Estado desde muito tempo, conforme nosso autor, Castro (2006: 135), é que existisse um certo afastamento desses povos das suas referências indígenas sob a narrativa “esse pessoal não é mais índio, nós lavamos as mãos. Não temos nada a ver com isso. Liberem-se as terras deles para o mercado; deixe-se eles negociarem sua força de trabalho no mercado". Há, aí, o que o nosso autor entende como um processo de "desindianização, ao reconhecer que ele não se tinha completado" (CASTRO, 2006: 141). Assim, tal processo aparentava ser estratégia para tornar os indígenas uma população capaz de servir ao Estado. Diante disso, as lideranças indígenas foram entendendo que o retorno ao desejo de ser indígena seria um afeto interessante, pelo qual se operaria uma torção na ideia de que ser indígena era o mesmo que sofrer; com essa torção, ser indígena se tornaria um lugar de afirmação. Esse desejo fez pensar que um índio é parte integrante de lugares chamados comunidade e povo (CASTRO, 2006). Ora, 
tais lugares constituem seus modos de ser e devir, baseando-se nas relações coletivas e não propriamente da aparência individual; daí a seguinte questão pensada a partir de nosso autor:

Nosso objetivo político e teórico, como antropólogos, era estabelecer definitivamente não o conseguimos, mas acho que um dia vamos chegar lá - que o índio não é uma questão de cocar de pena, urucum e arco e flecha, mas sim uma questão de "estado de espírito". Um modo de ser e não um modo de aparecer. Na verdade, mais do que isso, a indianidade designava um modo de devir (CASTRO, 2006: 136).

Tal noção foi pertinente para instituir uma constituinte de 1988 que levasse em consideração a questão dos povos originários. Daí a emergência das comunidades indígenas, que já anteriormente à constituinte se encontravam em tramas políticasreligiosas-culturais de desindianização, a qual as distanciava de suas apropriações, numa tremenda homogeneização das etnias, línguas, povos, regiões e religiões. Num verdadeiro projeto cujo alvo é a morte da diferença. Que índio é esse?

Mas então, veríamos aí, por parte desses povos, um movimento de reindianização? Apropriação e afirmação de si. Porém, se todos dizem ser índios hoje, quem afinal pode ser índio e que índio é esse? Seria o Estado (como perito), ou seriam os próprios indígenas os protagonistas e autores dessas respostas? Quais os efeitos disso tudo? Que devir é esse?

Talvez, ainda que o exercício do poder e do saber nos coloque sobre o outro na atividade de periciá-lo (FOUCAULT, 2017). Não caberia reduzir nosso trabalho ao ato de dizer se ele é autenticamente pertencente a uma identidade, modo de ser ou devir, por mais que tenhamos nossa boa vontade, engajamento ou aproximação teórica com tais problemáticas. O outro é sempre outro do que imaginamos, naquilo que ele pode falar e fazer por si. Ou seja, falar em primeira pessoa ainda é um exercício de dignidade possível. Podemos pensar e incorporar um exercício que nosso autor, Castro (2006), pensa a partir da antropologia, que talvez seja preciso entender que só quem é indígena pode responder a pergunta: quem é indígena? ou quem pode entrar na lista? Com efeito, tais questões partem mais do interesse do Estado - a partir da criação das suas leis, estatutos e projetos - do que propriamente dos interesses dos indígenas (FOUCAULT, 2017). Estes sabem desde muito tempo que não precisam provar suas identidades, modos de ser, devir e as condições de felicidade que sustentam suas referências. Ou ainda, talvez coubesse a nós acadêmicos dizer e elaborar uma outra questão a partir de um outro lugar de fala (RIBEIRO, 2019): afinal, quem não é indígena? Mas, ainda na elaboração dessa nova questão não cairemos numa nova armadilha, que é a perícia do outro? Quem seria esse outro? Que índio é esse? 
Poderíamos dizer que é interessante quando dessas questões entendemos como as redes de relações num dado espaço-tempo se auto-determinam e passam a constituir a realidade das suas vidas (CASTRO, 2006). Para o autor, a partir da constituição consagrou-se que as comunidades indígenas constituem-se como verdadeiros sujeitos coletivos de direitos coletivos, algo inverso ao que propuseram os projetos de emancipação, os quais versam emancipar individualidades num objetivo inteiramente óbvio, que é sujeitá-las às políticas de Estado. Portanto, há “[...] indígenas porque eles são membros de comunidades indígenas, e não o inverso" (CASTRO, 2006: 140). São parentes uns dos outros não apenas por consanguinidade ou genética, mas, também, por afinidade uns com os outros nas relações nas quais vivenciam vínculos afetivos, interpessoais, históricos, culturais e sociopolíticos. Para isso, nosso autor entende que:

Temos de trabalhar nesse contexto, pois esse é o contexto que está aí, mas sem com isso ter que trabalhar por este contexto, sem ter de vender nossa alma, e sem ter de acreditar na história da carochinha que se conta (que se conta quase sozinha), a história de que indio é uma entidade contábil (CASTRO, 2006: 151).

Nesse caso, para o autor não haveria índios, mas sim uma rede de relações numa respectiva comunidade nas quais seus membros podem se nomear enquanto indígenas. Como aponta Krenak em "A Potência do Sujeito Coletivo" (s/d) essa rede de relações se faz por se

Ter acesso comum a água, ao rio, ao lugar onde você podia buscar comida, acesso de sociabilidade que envolvia muitas pessoas. Esses coletivos, é isso que chamam de comunidade. Eu acho que quando nomeiam esses coletivos de comunidades esvaziam um pouco a potência que eles têm, e plasma uma situação idealizada de comunidade não conseguem problematizar a vida dessas pessoas. Sacar uma biografia em um ambiente desses é uma maneira de iluminar todo esse ambiente e projetar sentido na vida de todo mundo.

Diante disso, é possível suspeitarmos que não existe especificamente um sujeito que se possa dizer indígena, mas uma trama que se compartilha e torna indígenas os humanos tecidos nessa trama, quando tudo aí é compartilhado e só pode ser iluminado de uma só vez, por um olhar que inclui tudo e todos ali constituídos, especialmente, tudo aquilo que é inumano. Não haveria propriamente uma subjetividade, mas uma territorialidade e um agenciamento, os quais secretariam os indígenas tão somente como esse coletivo de potências e vidas.

Algo visível e invisível ao mesmo tempo, "mas nem por isso menos eficaz: um movimento infinitesimal incessante de diferenciação, não um estado massivo de 
“diferença" anteriorizada e estabilizada, isto é, uma identidade" (CASTRO, 2006: 137). Esta noção também aparecerá num outro autor, Santos (2015: 38), que diz que tal movimento e composição é "visível e palpável materialmente e pode ser sentida imaterialmente, tanto quando olhamos para o passado e fazemos referência aos nossos ancestrais, como hoje quando visitamos as comunidades da atualidade e dialogamos com as suas organizações e manifestações culturais". Assim, percebe-se aí um modo de vida que se faz na coletividade das forças, sendo a coletividade um vetor de constituição do comum. Isto é, como estas inumanidades se encontram com as humanidades e constituem o corpo? Ou então, nesse caso, seria o nosso grande desafio conhecer como o outro se auto-determina nas suas relações de parentesco (afinidade) ou vizinhança (transmissão intergeracional) com essas forças? Pois se todos disserem que são índios, quem não é afinal? Se todos se tornam índios ao devirem o tempo todo, o que é o ser de um índio? Não seria esta última, uma falsa pergunta atravessada de racionalidade europeia moderna?

Para Castro (1986), a noção de pessoa como estando baseada numa identidade consigo mesmo é incompatível com o processo de constituição indígena, especialmente, dos Tupi-Guarani. Para o autor, entre os Tupi-Guarani, alguém sempre está encarnando um entre-espaço, sempre está em devir; haveria um movimento centrífugo constante no processo de constituição "subjetivo" desses indígenas, que nos impediria completamente de conseguirmos estabelecer linhas taxonômicas e representações funcionais no interior de seus modos de existência comunitária. Tanto cada indivíduo - por assim dizer -, quanto o próprio corpo social estariam sempre saltando para uma zona ao mesmo tempo aquém e além do social, voltando-se para um exterior ou se deixando ser inteiramente atravessado por esse exterior, que é - diríamos precariamente com nossas palavras ocidentais - essencialmente cosmológico. Assim, um indígena, pelo menos um TupiGuarani, não teria Ser, mas somente devires, devires relativos à emergência de seu coletivo na relação imanente com essa exterioridade cosmológica.

Nas palavras de Castro, por causa dessa forma de constituição, é comum entre os ameríndios que eles considerem que tudo no mundo possua uma alma potencialmente humana, mas que, como tal, só se perfaça sendo outra coisa. "Se todos os seres têm alma, nenhum deles, ninguém, coincide consigo mesmo. Se tudo pode ser humano, então nada é humano inequivocamente" (CASTRO, 2015: 62). Como já se apontava a partir do relato de Krenak, é somente a partir de uma trama coletiva de elementos inumanos que se pode definir a humanidade indígena. Assim, Castro (2015) mostra que, para os ameríndios, ser humano é imediatamente ocupar uma posição existencial em que imediatamente já se está 
tramado e entremeado por outros seres, porque todos os seres têm humanidade. Neste sentido, tudo o que é humano, só pode ser descrito pelo movimento intempestivo de tornar-se, ou seja, pelo devir que se prolonga necessariamente na posição de um outro ser, uma queixada, um jaguar, um rio, uma erva, a Lua. A cosmovisão ameríndia, destaca Castro (2015), inverte o axioma ontológico da modernidade branca: "eu penso, logo existo" (ou "logo sou") é virado em direção a "isto existe, logo isto pensa", quer dizer, isto que existe posiciona-se imediatamente como aquilo que eu também sou e que me torno. Então, a partir dessa visão, os humanos guardam com todos os seres uma relação de continuidade diferencial, que os faz estarem em comunidade ontológica a partir dos devires; nesta visão ameríndia tratar-se-ia, se compreendemos bem, de vermos um mesmo tecido (cosmo)ontológico a constituir os humanos e inumanos, enquanto existentes que só podem emergir a partir de um único e multiplicitário gesto de co-criação, existentes que se engendram de uma vez só, junto com tudo o que existe no mundo. Uma igualdade encontrada na multiplicidade de existentes e na diferenciação não substancial da existência?

Se é mesmo isso, Krenak (s/d) é quem nos confirma, quando diz que o sentimento de interagir com outros iguais "é fundamental para sermos uma pessoa equilibrada. Você não fica o tempo todo tendo que fazer ajuste para se relacionar. Você fica à vontade numa comunidade.” Então, aqui, encontramos mais uma pequena e escorregadia pista de uma ética decolonial para a pesquisa: nossas existências só ganham força de vida a partir dos devires que não suspeitamos haver entre nós, mas que necessariamente compartilhamos. É nisso que se desemboca em se assumir não haver possibilidade de se apontar quem não seja indígena, pois um indígena necessariamente está sendo outra coisa, está no processo de tornar-se junto com o mundo. Ora, segundo essa cosmovisão ou (cosmo)ontologia, nós, não-indígenas, também estaríamos necessariamente e inescapavelmente envolvidos nesse processo, uma vez que somos seres do mesmo mundo.

Portanto, a pista decolonial aqui nos direciona a encarnarmo-nos como simples afectos de um processo do mundo e não como descobridores de substâncias desse mundo. Quem é o indígena, senão aquilo que precisamos nos tornar para sermos humanos de fato e de afecto?

\section{Linha aberta: o que realizar antes do fim?}

Assim, sem vender o nosso amanhã, nos esforcemos para não fantasiarmos o “depois", para não relegarmos nosso futuro a outro mundo, a um mundo de contos de 
fadas, pois "a ideia de nós, os humanos nos descolarmos da terra, vivendo numa abstração civilizatória é absurda. Ela suprime a diversidade, nega a pluralidade das formas de vida, de existência e de hábitos" (KRENAK, 2019: 23). Se pudermos contar mais uma linha da história no meio das "grandes narrativas", estaremos assim olhando para o passado e enxergando no atual as linhas fugidias que escapam da dureza daquilo que se impõe ao outro como verdade universal. E entre as fugidias linhas uma centelha que nos faz aprender algo com o passado: de que não são os indígenas, os caboclos, as ONG's e a imprensa que estão ateando fogo no pantanal ou na Amazônia. Assim, sem esperar pelo juízo final, aprende-se a história olhando para o presente, sem esquecer o passado. Tornamo-nos contemporâneos quando esticamos nosso presente numa linha crítica desse mesmo tempo atual. Para tanto, "escovar a história contrapelo" seria então sustentar esse trabalho de abertura das linhas escritas na dureza da história universal (BENJAMIN, 1987: 225). Ou seja, olhar a vida por outros ângulos e com outros olhos, criando outras experiências possíveis, acessando o mundo em outramentos, perceptos e percepções, sem que para isso tenhamos que cair no perigo de pautar a vida do outro a partir de uma postura de peritos.

A postura de perito que acaba sendo compatível com as ideias das políticas de governo do Estado, que buscam policiar, avaliar, controlar e gerir, têm por objetivo uma biologização da vida que acaba por torná-la pobre e desprovida de experiências alegres (FOUCAULT, 2017). Isto tem nada menos como corolário: um hiperativo dentro dos modos de vida, cujo o Estado é o aparelho tecnológico no qual o "[...] objetivo do exercício do poder será manter, reforçar e proteger o principado [...]” (FOUCAULT, 2017: 410). Diante disso, tornar todos os brasileiros indígenas, ou, talvez, tornar os indígenas em cidadãos civilizados, assemelha-se às práticas de governo das vidas, nas quais não mais são os governantes, mas agora são “as pessoas que governam, as práticas de governo são, por um lado, práticas múltiplas, à medida que muita gente pode governar" (FOUCAULT, 2017: 411). Dirá Foucault (2017), que todas essas práticas de governo estão dentro do Estado ou sociedades cuja modalidade de política pode existir em diferentes modos de governar, mas, também, poderá se reinventar na forma de variadas práticas e modos de governo. Logo, o que esses projetos de emancipação que se colocam sobre os povos originários têm como objetivo, nada mais é do que um controle a céu aberto, numa "pluralidade de formas de governo e imanência das práticas de governo com relação ao Estado" (FOUCAULT, 2017: 412). O sonho dessas práticas de governo é então criar e registrar uma descontinuidade desses modos de vida originários, torná-los sujeitos 
no sentido da palavra assujeitado, assim como torná-los indivíduos que não se dividem, numa vida desprovida das suas coletividades e experiências, desprovida dos devires que os tornam o que são em potência. Portanto, introduzir as políticas de Estado nas experiências indígenas sem o consentimento desses povos acaba por estabelecer uma forma de vigilância, de controle tão atenta quanto aquele que já atravessa as nossas pobres vidas cotidianas. Dirá nosso autor, que governar é governar as coisas, assim como:

Estas coisas, de que o governo deve se encarregar, são os homens, mas em suas relações com as coisas que são as riquezas, os recursos, os meios de subsistência, o território em suas fronteiras, com suas qualidades, clima, seca, fertilidade etc.; os homens em suas relações com outras coisas que são os costumes, os hábitos, as formas de agir ou de pensar etc.; finalmente, os homens em suas relações com outras coisas ainda que sejam os acidentes ou as desgraças como a fome, a epidemia, a morte etc (FOUCAULT, 2017: 415).

São as práticas de governo nada mais do que táticas de controle e regulação da vida que se impõem como um processo de homogeneização, isto é, tornar a diferença algo caricato ou formatado a partir da disposição das coisas "fazer, por vários meios, com que determinados fins possam ser atingidos" (FOUCAULT, 2017: 418). Assim, o Estado, com suas práticas de governo, entra num princípio de "governamentalidade", pelo qual governa fundando-se em regras racionais que lhe são próprias, o que equivale a pensar que tal aparelho não estabelece qualquer nível de entendimento ou aproximação com os saberes produzidos entre as relações humanas e inumanas do povos originários a não ser que possa governá-los (FOUCAULT, 2017: 429). Os saberes ou práticas do Estado se baseiam nos princípios de materialidade, concretude e racionalidade, naquilo que é construído como política de assistência à população, de modo que "gerir a população significa geri-la em profundidade, minuciosamente, no detalhe" (FOUCAULT, 2017: 428). Diante disso, podemos dizer que mais uma cinzenta linha ética de posicionamento decolonial para o fazer pesquisa talvez se encontre em atentarmo-nos, como nãoindígenas, a que tipo de produção social se direciona o saber que produzimos. Estaria ele se aproximando de certas populações, extraindo-lhes saber para que, mais profundamente, se preste a governá-las? Estaria ele desejando saber para ciclopicamente apenas antever empreendimentos do presumido progresso? Aquilo que voluntariamente colocamos a serviço do pesquisar estaria suficientemente deslocado de uma razão de governo, especialmente junto de coletividades ancestrais de nossos territórios? Quem são os indígenas que delineamos com nossos saberes e qual o seu espaço existencial quando essas nossas trajetórias epistemológicas podem determinar as territorialidades estatais que 
irão se açambarcar sobre eles? Estas seriam algumas perguntas que também funcionam, a seu modo, como pistas de um cuidado ético para não cairmos na colonialidade governamental do Estado.

Enfim, toda essa discussão não pretende formatar uma verdade a respeito do que é ou deve ser indígena, ou, talvez, o que estes precisam fazer; porém, vale lembrar que, frente aos acontecimentos do intempestivo tempo que vivemos, estamos nós, nãoindígenas, implicados a partir de algum lugar com estas questões. Implicação esta em construir um mundo comum no qual todos e todas possam habitar. Estas reflexões tiveram como tentativa criar discussões que pudessem brevemente nos aproximar dos modos de vida dos indígenas e das tantas outras linhas que os circundam na atualidade da arbitrariedade do Brasil - na sua ficção pela homogeneidade, empreendedorismo, privatização. Também quisemos entender parte daquilo que os indígenas experimentam enquanto processo constituinte dos seus modos de vida em comunidade, enquanto força coletiva em fruição com os seres humanos e inumanos. Não cabe, portanto, à academia direcionar as condições éticas-políticas-estéticas para que os povos da floresta se articulem pelos seus territórios-existenciais; contudo, muito menos cabe se abastar dessas questões. Por isso tracejamos aqui uma tentativa de localização de pistas, ainda que enuviadas e frágeis, de posições éticas passíveis de serem tomadas no direcionamento de estabelecermos uma relação possível com as coletividades indígenas, porém, imbuídos de um esforço de localização epistemológica decolonial. Uma vez que não estamos descolados desse mundo e muito menos somos o sal dessa terra, ainda que por vezes fantasiamos perversamente sermos os juízes do saber, vale lembrar o que disse o nosso autor, Krenak (2020: 58), "se continuarmos comendo o planeta, vamos todos sobreviver por só mais um dia”. Assim, falar do presente é não esquecer do passado, falamos então do futuro no aqui e agora, sem precisar vender o amanhã. Então, sem banalizar o que nos acontece, vamos procurar fazer algo frente a isto que é intempestivo, pois, como dito, só é indígena quem se garante, pois e agora: será que nós não-indígenas conseguimos nos garantir frente aos acontecimentos do mundo? Qual devir-indígena precisamos encarnar para garantirmos um pedaço são de futuro?

Devemos nos orgulhar de que ainda existam comunidades indígenas assegurando um modo vida outro possível nas terras tropicais, um modo de vida corajoso e que se integra numa fruição com o organismo terra, pois a partir daí podemos nos perguntar: o que pode a vida na sua diferença? Podemos acompanhar com certa recorrência alguns líderes indígenas ocupando lugares discursivos antes não ouvidos e enxergados. Mas, 
sabemos que, no Brasil, sempre se teve vergonha dos indígenas, o que revela a dificuldade de nosso povo citar e se referenciar no seu passado. Esse exercício de deslocamento histórico e ético é algo complexo e que não será resolvido por um ensaio como este, mas que será resolvido e elaborado por mobilizações políticas, coletivas e individuais; por isso a importância de se pensar o lugar de implicação dos não-indígenas na produção de pesquisas. No entanto, todas essas discussões só tomarão a devida relevância caso nós, não-indígenas, nos inquietarmos frente às provocações realizadas. Ou talvez, não menos importante, caso os povos originários qualifiquem e validem tudo o que acabamos de escrever. Não por avaliarmos ou constatarmos algo sobre os seus modos de vida, mas por pensarmos que, talvez, uma aliança seja algo pertinente para construirmos um outro modo de vida possível, pois, como já intitulado: isto não é um índio.

\section{Referências}

ADICHIE, Chimamanda Ngozi. N. O perigo de uma história única. São Paulo: Companhia das Letras, 2009.

AGAMBEN, Giorgio. O que é o contemporâneo? E outros ensaios. Chapecó: Argos, 2009.

BENJAMIN, Walter. Experiência e pobreza. In: BENJAMIN, Walter. Magia e técnica, arte e política: ensaios sobre literatura e história da cultura. São Paulo: Brasiliense, 1987. p. 114-119.

BENJAMIN, Walter. Sobre o conceito de história. In: BENJAMIN, Walter. Magia e técnica, arte e política: ensaios sobre literatura e história da cultura. São Paulo: Brasiliense, 1987. p. 222-234.

BENJAMIN, Walter. Sobre o conceito da história. In: BENJAMIN, Walter. Walter Benjamin: o anjo da história. Belo Horizonte: Autêntica Editora, 2012.

CASTRO, Eduardo Batalha Viveiros de. Arawté - Os Deuses Canibais. Rio de Janeiro: Jorge Zahar, 1986.

CASTRO, Eduardo Batalha Viveiros de. "No Brasil todo mundo é índio, exceto quem não é”. In: CASTRO, Eduardo Batalha Viveiros de. Entrevistas com Eduardo Batalha Viveiros de Castro. Série: Encontros. Rio de Janeiro: Azougue Editorial, 2006, p. 130-161.

CASTRO, João Henrique. Indígenas fecham parte da Estrada de Ferro da Vale, em Aracruz. A Gazeta. Vitória, 6 de fevereiro, em 2020. Disponível em: $<$ https://www.agazeta.com.br/es/norte/indigenas-fecham-parte-da-estrada-deferro-da-vale-em-aracruz-0220> Acesso em: 01 de Outubro, em 2020.

DELEUZE, Gilles; GUATTARI, Félix. Mil platôs: Capitalismo e Esquizofrenia, Vol. 4. São Paulo: 34, 1997.

DELEUZE, Gilles. Diferença e Repetição. Rio de Janeiro: Graal, 2006.

DELEUZE, Gilles. Conversações. São Paulo: Editora 34, 2013. 
FOUCAULT, Michel. A governamentalidade. In: FOUCAULT, Michel. Microfísica do poder. Rio de Janeiro/São Paulo: Paz e Terra, 2017, p. 407-431.

GIACOMO, Fred di. Eleito intelectual do ano, Aílton Krenak ensina: "A vida não é útil". 01 de Outubro, em 2020. São Paulo, 01 de Outubro, em 2020. Disponivel: $<$ https://www.uol.com.br/ecoa/colunas/arte-fora-dos-centros/2020/10/01/eleitointelectual-do-ano-ailton-krenak-ensina-a-vida-nao-e-util.htm> Acesso em: $01 \mathrm{de}$ Outubro, em 2020.

KRENAK, Ailton. A potência do sujeito coletivo. Parte I. Revista Periferias. (s/d) Disponível em: http://revistaperiferias.org/materia/a-potencia-do-sujeitocoletivo-parte-i/?ided=23 Acessado em 10/10/2020.

KRENAK, Ailton. Ailton Krenak - Discurso na Assembleia Constituinte. Youtube. Brasília, 16 de fev, de 2018. Disponível: <https://www.youtube.com/watch?v=TYICwl6HAKQ\&t=58s> Acesso em: 01 de Outubro, em 2020.

KRENAK, Ailton. A vida não é útil. São Paulo: Companhia das Letras, 2020.

KRENAK, Ailton. Ideias para adiar o fim do mundo. São Paulo: Companhia das Letras, 2019.

LOURAU, René. Objeto e método da análise institucional. In: ALTOÉ, Sônia (org.). René Lourau: analista institucional em tempo integral. São Paulo: Hucitec, 2004, p. 66-86.

MAGRITTE, René. Ceci n'est pas une pipe. In: MAGRITTE, René. La trahison des images. Los Angeles, Museu de Arte do Condado, 1928-1929.

MARTINHO, Cássio. Tuíra, a imagem: Se a fotografia necessita do acontecimento para existir, ela por si só pode produzir ou inventar um acontecimento. Altamira, Pará, fevereiro, em 1989. Disponível em: <https://escoladeativismo.org.br/tuira-aimagem/> Acesso em: 01 de Outubro, em 2020.

MBEMBE, Achille. Necropolítica. Rio de Janeiro: Arte \& Ensaios, Revista do PPGAV/EBA/UFRJ, n ${ }^{\circ}$ 32, 2016.

MBEMBE, Achille. Necropolítica. São Paulo: n-1 edições, 2020.

RIBEIRO, Djamila. Lugar de fala. São Paulo: Sueli Carneiro; Pólen, 2019.

SANTOS, Antônio Bispo dos. Colonização, Quilombos: modos e significações. Brasília, DF: Unb, 2015.

Gustavo Alves Eduardo

Universidade Federal do Espírito Santo

Email: gustavoalvese@gmail.com

Fernando Hiromi Yonezawa

Universidade Federal do Espírito Santo

Email: fefoyo@yahoo.com.br 